\begin{tabular}{|c|c|c|c|}
\hline \multirow{3}{*}{$\begin{array}{r}\text { Case Reports in } \\
\text { Gastroenterology }\end{array}$} & \multirow{2}{*}{\multicolumn{2}{|c|}{ Case Rep Gastroenterol 2018;12:640-645 }} & \multirow[b]{3}{*}{$\begin{array}{l}\text { Karger } \\
\text { Open'access }\end{array}$} \\
\hline & & & \\
\hline & $\begin{array}{l}\text { DOI: 10.1159/000493919 } \\
\text { Published online: November 1, } 2018\end{array}$ & $\begin{array}{l}\text { (c) } 2018 \text { The Author(s) } \\
\text { Published by S. Karger AG, Basel } \\
\text { www.karger.com/crg }\end{array}$ & \\
\hline & $\begin{array}{l}\text { This article is licensed under the } C \\
\text { International License (CC BY-NC) ( } \\
\text { Usage and distribution for commercial }\end{array}$ & $\begin{array}{l}\text { mons Attribution-NonCommercial } 4.0 \\
\text { rger.com/Services/OpenAccessLicense). } \\
\text { quires written permission. }\end{array}$ & \\
\hline
\end{tabular}

\title{
A Rare Cause of Dysphagia and Weight Loss
}

\author{
Janelle B. Gyorffy ${ }^{a} \quad$ Johanna Marowske ${ }^{b} \quad$ John Gancayco ${ }^{b}$ \\ ${ }^{a}$ Department of Internal Medicine, San Antonio Uniformed Services Health Education \\ Consortium, San Antonio, TX, USA; bepartment of Gastroenterology, San Antonio \\ Uniformed Services Health Education Consortium, San Antonio, TX, USA
}

\section{Keywords}

Esophageal dysmotility · High-resolution esophageal manometry $\cdot$ Mixed connective tissue disease

\begin{abstract}
Mixed connective tissue disease (MCTD) is a rare connective tissue disorder with clinical features that overlap with systemic lupus erythematous, systemic sclerosis, and polymyositis. We report the case of a patient who presented with dysphagia, 25-lb weight loss, difficulty opening her mouth, and joint pain. Dysphagia workup showed a normal barium swallow and normalappearing EGD but esophageal manometry consistent with severe dysmotility. Through further laboratory and imaging studies, the patient met the diagnostic criteria for MCTD. She had marked improvement in her dysphagia with steroids, biologic therapy, and intravenous immunoglobulin.

(c) 2018 The Author(s)

Published by S. Karger AG, Basel
\end{abstract}

\section{Introduction}

Mixed connective tissue disease (MCTD) is a rare disorder with an estimated incidence 2.1 per million per year [1]. It is referred to as an "overlap" syndrome, as clinical manifestations can be a mix of symptoms seen in scleroderma, polymyositis, and systemic lupus erythematous. Almost any organ system can be involved, with esophageal symptoms being among the most common presentations (45-80\%). Heartburn (48\%) and dysphagia (38\%) 


\section{Case Reports in Gastroenterology}

Case Rep Gastroenterol 2018;12:640-645

DOI: $10.1159 / 000493919$

(c) 2018 The Author(s). Published by S. Karger AG, Basel www.karger.com/crg

Gyorffy et al.: A Rare Cause of Dysphagia and Weight Loss

are the most common gastrointestinal symptoms reported in MCTD, but many patients may be asymptomatic [2]. A thorough gastroenterology workup may be warranted to exclude other etiologies of esophageal disorders.

\section{Case Report}

A 54-year-old African-American female presented with 3 months of progressive painless dysphagia. She reported "jaw locking" with eating and had an unintentional 25-lb weight loss (baseline weight $160 \mathrm{lbs}$ ). The patient complained of new joint pain in her hands, periorbital rash, and alopecia. Physical examination was notable for temporal wasting, inability to open her mouth more than $1 \mathrm{inch}$, and bilateral sclerodactyly. Initial laboratory studies were significant for a positive ANA $(1: 1,280)$. She underwent a barium swallow that showed normal swallow function with no mass, stricture, or evidence of aspiration. EGD showed a normal-appearing esophagus with a single nonobstructing Schatzki ring (Fig. 1). Random biopsies of the esophagus were only significant for scattered neutrophils. The patient underwent high-resolution esophageal manometry that showed normal lower esophageal sphincter pressure and normal relaxation after deglutition, but peristalsis was impaired with $80 \%$ failed swallows (Fig. 2). Her esophageal manometry results were consistent with ineffective esophageal motility.

The patient was evaluated by Rheumatology and found to have CK 7,207 IU/L (normal 24-170 IU/L), positive anti-RNP 57 Ehrlich units/mL, positive PM-SCL antibodies $>160 \mathrm{Ehr}-$ lich units/mL, positive anti-RNP 57 Ehrlich units/mL, positive RNA polymerase antibody 20.4 $\mathrm{U} / \mathrm{mL}$, positive PM-SCL 75, and positive PML-SCL 100. A high-resolution chest CT showed decreased lung volumes with fibrosis and traction bronchiectasis consistent with collagen vascular-associated interstitial lung disease (ILD). Pulmonary function tests showed a restrictive pattern. MRI of the lower extremities showed bilateral edema and inflammatory changes involving bilateral thigh muscles. The patient met the diagnostic criteria for MCTD based on the Kasukawa classification with positive anti-RNP antibodies (common symptoms), sclerodactyly, pulmonary fibrosis, elevated CK ( $>1$ finding in two categories). With the constellation of symptoms, laboratory results, and imaging findings, she was diagnosed with MCTD with predominant myositis features.

The patient was started on high-dose prednisone and intravenous immunoglobulin with improvement in her symptoms. She could be transitioned to low-dose prednisone, mycophenolate mofetil, hydroxychloroquine, and intravenous immunoglobulin for long-term therapy. Her dysphagia improved and she was able to regain her baseline weight. Her CK decreased to 286 IU/L (normal 24-170 IU/L). She underwent repeat esophageal manometry 6 months after starting treatment which showed normal lower esophageal sphincter resting pressure and normal esophageal motility with 70\% normal swallows (Fig. 3).

\section{Discussion}

MCTD is frequently associated with esophageal dysmotility, with GERD and dysphagia being the most frequently reported clinical manifestations. Esophageal dysmotility in MCTD can be subclinical at onset, and up to one-third of patients with abnormal manometry tests are asymptomatic [2-5]. Esophageal manometry has demonstrated that changes in motility are typically due to aperistalsis in the lower two-thirds of the esophagus, but can also involve 
the proximal striated muscle and is generally less severe than in scleroderma $[2,6]$. Serious complications include esophagitis, strictures, and Barrett's esophagus. Abnormal peristalsis can also occur in other parts of the gastrointestinal tract to include delayed gastric emptying and delayed bowel transit [3].

The pathogenesis for dysmotility in patients with MCTD is unknown. One hypothesis is that autoantibodies attack smooth muscle tissue in the esophagus as well as ganglion cells in the Auerbach plexus, vascular walls, muscular tissue, and squamous epithelium contributing to the dysphagia [7]. Postmortem analysis has shown histopathologic changes more severe in the lower two-thirds of the esophagus and in the inner circular muscular layer of the esophagus [8].

The patient also had a restrictive pattern on pulmonary function tests and CT imaging consistent with ILD. Pulmonary involvement in MCTD is common and often coexists with esophageal motor impairment. Fagundes et al. [9] found a significant correlation between severe esophageal motor dysfunction and ILD in patients with MCTD. The pathologic mechanism underlying the formation of ILD is unclear, with conflicting evidence on the role of gastroesophageal reflux due to esophageal dysmotility $[10,11]$. Pulmonary complications include aspiration pneumonia, pulmonary fibrosis, and pneumonitis [5].

In conclusion, we report the unique case of a patient newly diagnosed with MCTD after presenting with initial dysphagia symptoms. Laboratory, imaging, and clinical symptoms were used to determine the diagnosis of MCTD. A high suspicion for rheumatologic etiologies should be maintained when a patient presents with dysphagia and the appropriate clinical syndrome.

\section{Statement of Ethics}

The authors have no ethical conflicts to disclose.

\section{Disclosure Statement}

The authors declare that there is no conflict of interest regarding the publication of this article. The views expressed are those of the authors and do not reflect the official policy of the Department of the Air Force, the Department of the Army, the Department of Defense, or the United States Government.

\section{Funding Sources}

There was no funding provided for this research.

\section{Author Contributions}

Dr. Gyorffy wrote the manuscript. Dr. Marowske and Dr. Gancayco provided the images and edited the manuscript. 
Gyorffy et al.: A Rare Cause of Dysphagia and Weight Loss

\section{References}

1 Gunnarsson R, Molberg 0, Gilboe IM, Gran JT; PAHNOR1 Study Group. The prevalence and incidence of mixed connective tissue disease: a national multicentre survey of Norwegian patients. Ann Rheum Dis. 2011 Jun;70(6):1047-51.

2 Schneider HA, Yonker RA, Longley S, Katz P, Mathias J, Panush RS. Scleroderma esophagus: a nonspecific entity. Ann Intern Med. 1984 Jun;100(6):848-50.

3 Nica AE, Alexa LM, Ionescu AO, Andronic 0, Păduraru DN. Esophageal disorders in mixed connective tissue diseases. J Med Life. 2016 Apr-Jun;9(2):141-3.

4 Marshall JB, Kretschmar JM, Gerhardt DC, Winship DH, Winn D, Treadwell EL, et al. Gastrointestinal manifestations of mixed connective tissue disease. Gastroenterology. 1990 May;98(5 Pt 1):1232-8.

5 Ling TC, Johnston BT. Esophageal investigations in connective tissue disease: which tests are most appropriate? J Clin Gastroenterol. 2001 Jan;32(1):33-6.

6 Doria A, Bonavina L, Anselmino M, Ruffatti A, Favaretto M, Gambari P, et al. Esophageal involvement in mixed connective tissue disease. J Rheumatol. 1991 May;18(5):685-90.

7 Reichlin M. Problems in differentiating SLE and mixed connective-tissue disease. N Engl J Med. 1976 Nov;295(21):1194-5.

8 Kamataki A, Uzuki M, Sawai T (September 2nd 2015). Histopathological Change of Esophagus Related to Dysphagia in Mixed Connective Tissue Disease, Seminars in Dysphagia Renee Speyer and Hans Bogaardt, IntechOpen, DOI: 10.5772/60509. Available from: https://www.intechopen.com/books/seminars-indysphagia/histopathological-change-of-esophagus-related-to-dysphagia-in-mixed-connective-tissuedisease.

9 Fagundes MN, Caleiro MT, Navarro-Rodriguez T, Baldi BG, Kavakama J, Salge JM, et al. Esophageal involvement and interstitial lung disease in mixed connective tissue disease. Respir Med. 2009 Jun;103(6):854-60.

10 Marie I, Dominique S, Levesque H, Ducrotté P, Denis P, Hellot MF, et al. Esophageal involvement and pulmonary manifestations in systemic sclerosis. Arthritis Rheum. 2001 Aug;45(4):346-54.

11 Troshinsky MB, Kane GC, Varga J, Cater JR, Fish JE, Jimenez SA, et al. Pulmonary function and gastroesophageal reflux in systemic sclerosis. Ann Intern Med. 1994 Jul;121(1):6-10.
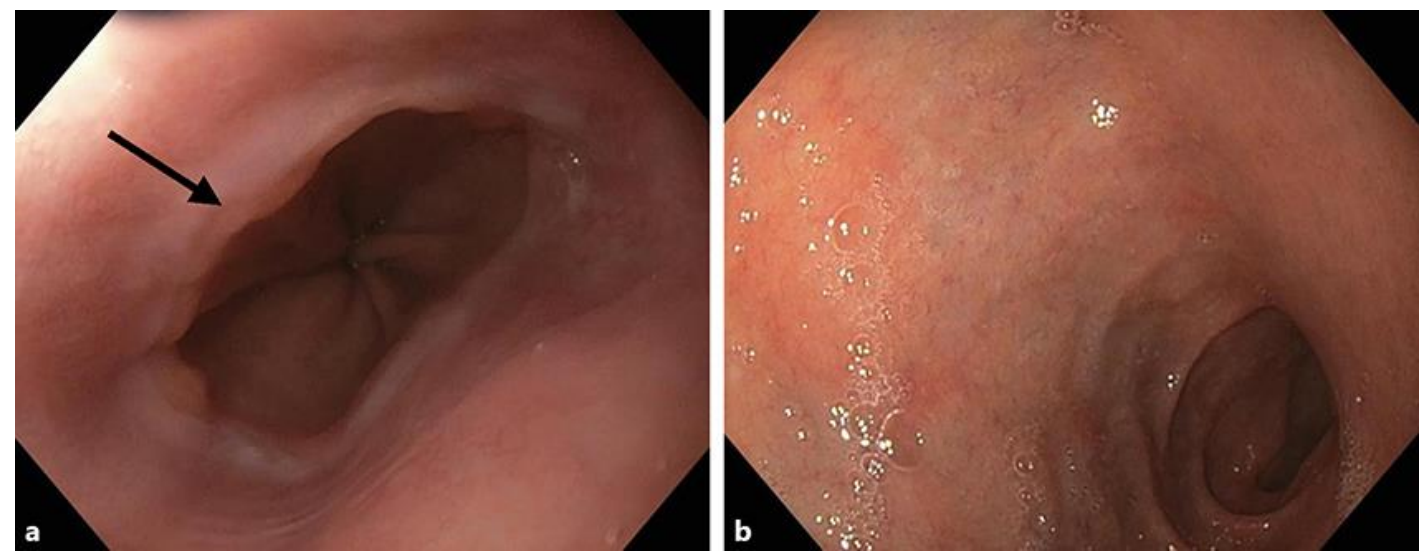

Fig. 1. The patient's initial EGD showed a Schatzki ring (arrow) (a) but was otherwise largely normal-appearing (b). 


\begin{tabular}{|c|c|c|}
\hline \multirow{2}{*}{$\begin{array}{l}\text { Case Reports in } \\
\text { Gastroenterology }\end{array}$} & \multicolumn{2}{|c|}{ Case Rep Gastroenterol 2018;12:640-645 } \\
\hline & DOI: $10.1159 / 000493919$ & $\begin{array}{l}\text { () } 2018 \text { The Author(s). Published by S. Karger AG, Basel } \\
\text { www.karger.com/crg }\end{array}$ \\
\hline
\end{tabular}

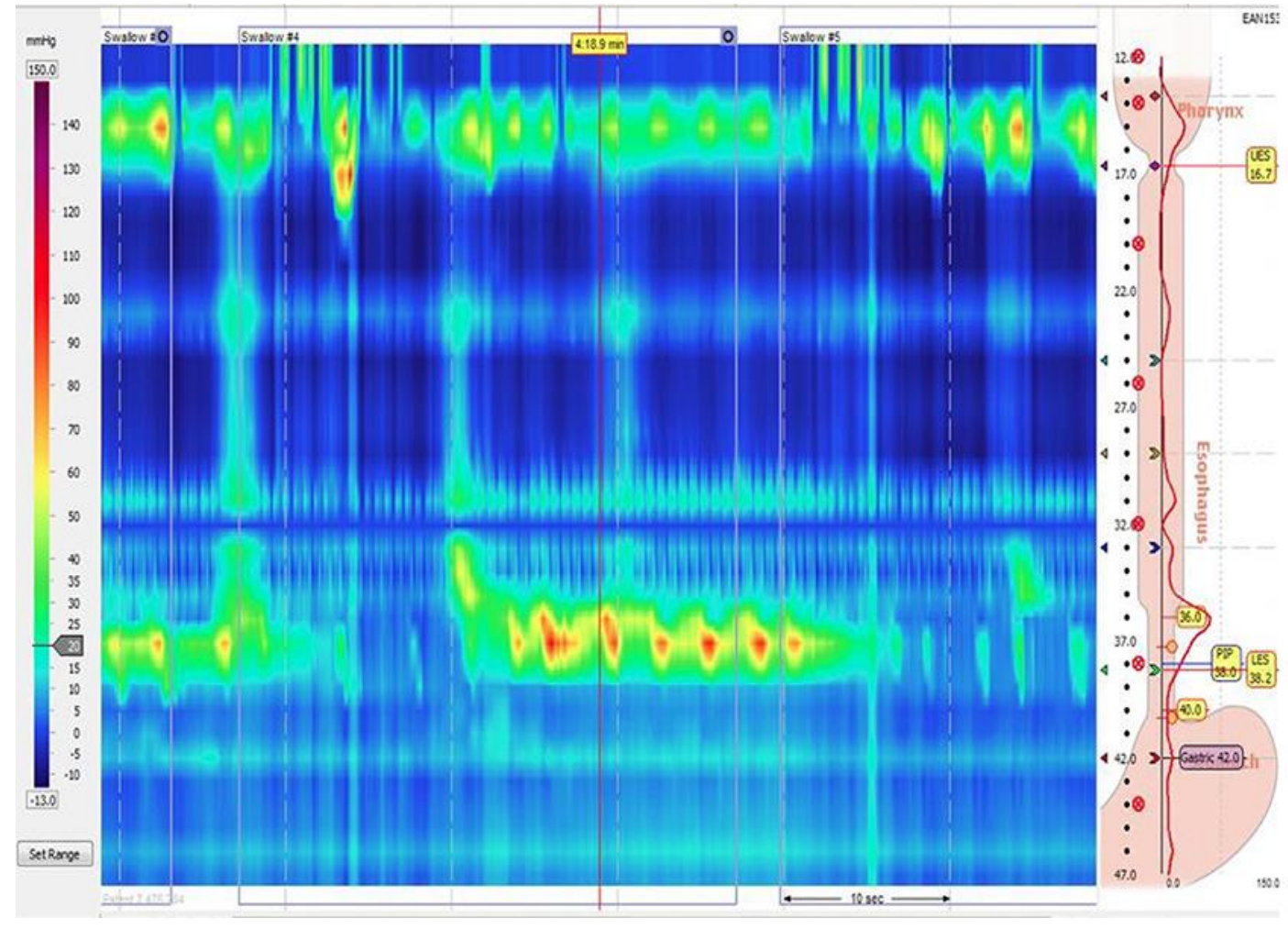

Fig. 2. The patient's initial high-resolution esophageal manometry showed low-amplitude contractions with swallowing consistent with ineffective esophageal motility. 


\section{Case Reports in Gastroenterology}

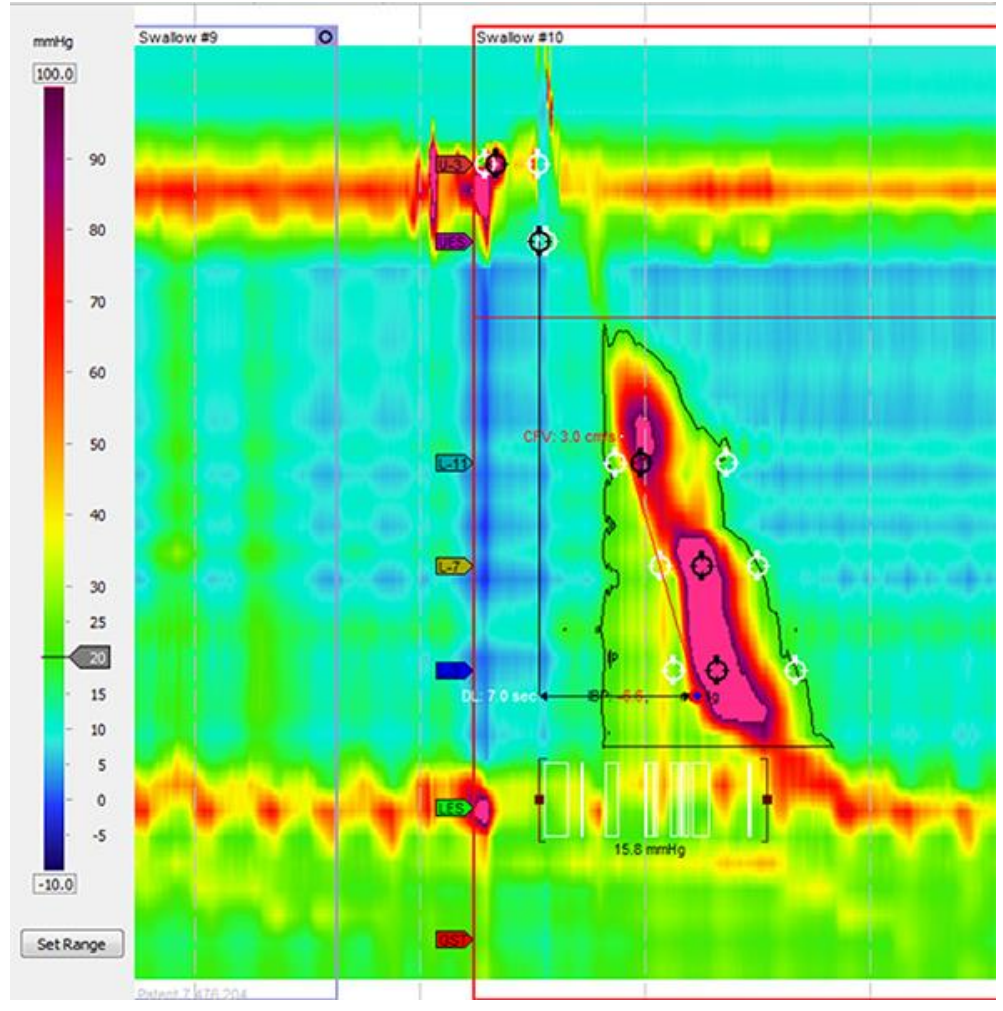

Fig. 3. Repeat high-resolution esophageal manometry after 6 months of therapy showed an intact contraction pattern with mildly impaired relaxation of the lower esophageal sphincter. Esophageal motility was markedly improved with $70 \%$ normal swallows. 